\title{
Inclusive design - assistive technology for people with cerebral palsy
}

\author{
Regina Heidrich ${ }^{\mathrm{a},}{ }^{*}$, Patrícia Bassani ${ }^{\mathrm{b}}$ \\ ${ }^{a}$ LABIE - Laboratório de Inclusão e Ergonomia. RS-239, 2755, Hamburgo Velho. Novo Hamburgo-RS. CEP \\ 93352-000 \\ ' ICET, University Feevale, pbassani@feevale.br, RS, Brasil
}

\begin{abstract}
The first sentence of the Abstract should follow the word "Abstract." on the same line. The abstract should be clear, descriptive, self-explanatory and no longer than 200 words. It should also be suitable for publication in abstracting services. Do not include references or formulae in the abstract. This study reports the work of the Inclusive Design research project conducted with a group of children with cerebral palsy Our project has been working with Assistive Technology and has been developing an expanded mouse and a keyboard. Nowadays, we are working as a researcher of Cognitive Ergonomics and of Inclusive Education. The goal of our project is to establish an interdisciplinary study that focus the developing of a research in Ergonomics Design, contributing to improve the assistance to people with special needs. Method: One applied the pedagogical approach, using Vygotsky's Social-historic Theory that advocates the concept of each individual's experiences are important to improve them. The development methodology was based on user-centered design. Results: The results showed that as long as the students applied the new technologies they developed superior psychological processes towards social interaction, autonomy, taking part in class activities more efficiently. Also, we verified how important the new technologies in class were, considering the methodologies, objectives full and effective described on this study. This way, we do hope, from the data obtained on this research, to contribute with the ones who believe that the improvement of handicap students' inclusion in class is a reality.
\end{abstract}

Keywords: cerebral palsy, Assistive Technology, Cognitive Ergonomics, Inclusive Education

\section{Introduction}

Social and school inclusion using ICT (information and communication technologies) has been a widely discussed topic by several professionals (Heidrich, 2004, Santarosa, 2002, Passerini, 2005, Tijiboy, 2001). According to Neri (2003), science and technology are part of the investment required to facilitate the inclusion of people with disabilities, since many innovations in these areas can reduce individual motor requirements, thus eliminating some functional barriers.

According to the Optional Protocol to the Convention on the Rights of Persons with Disabilities (2009), people with disabilities are "those who have long-term physical, mental, intellectual or sensory impairments which in interaction with various barriers may hinder their participation in society on an equal basis with others." In order to provide equal conditions, the use of ICT is crucial for individuals with cerebral palsy.

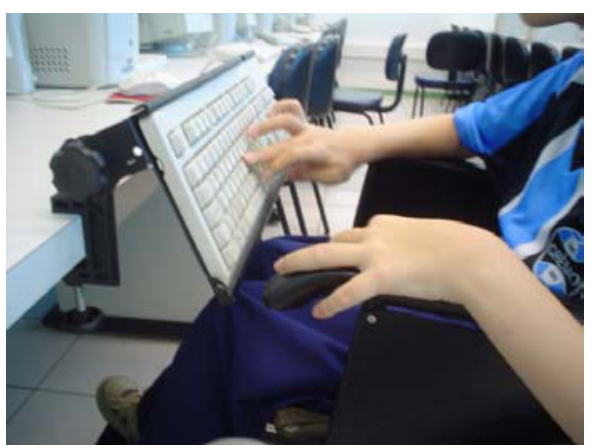

Figure 1 - Ergonomic support of keyboard used by child with cerebral palsy

\footnotetext{
* Corresponding author. Email: rheidrich@feevale.br
} 


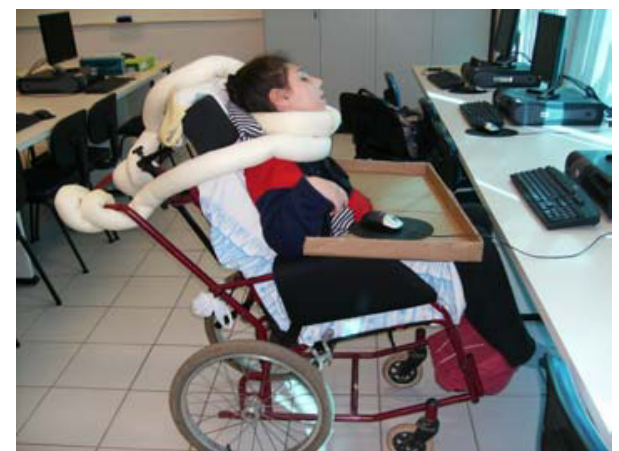

Figure 2 - Assistive Technology used by child with cerebral palsy

The first description of cerebral palsy (CP) was made in 1843 by William John Little, in which it was referred to as "Little's Syndrome" and characterized by muscle stiffness caused by asphyxiation of the newborn (LIMA and FONSECA, 2004). The first description of this encephalopathy characterized by muscle stiffness predominantly in lower limbs was presented by William John Little in 1943, and the term CP was introduced by Sigmund Freud, and later consolidated in the literature by Phelps. With the succession of studies, the concept became more comprehensive, and its causes were recognized as damages to central nervous system (CNS) during the pre, peri and post-natal periods (CIASCA et al, 2006).

$\mathrm{PC}$ is the result of an injury or maldevelopment of the brain, not progressive in nature, occurring when the brain is still immature and hindering the motor development of the child. Motor impairment is expressed by abnormal patterns of posture and movements associated with muscle tone (BOBATH, 1976). According to Lamônica (2004), PC is defined as a brain damage sequel disorder characterized by persistent and variable muscle tone, posture and movements, with onset in early childhood -- from conception until the first years of life.

Fonseca and Lelis (2008) conceptualize PC as an infant encephalopathy or chronic non-progressive neuromotor dysfunction, caused by lesions in the developing brain until the age of three and causing movement, muscle tone and posture disorders, which may or may not compromise cognitive functions.

\section{Development methodology for learning objects}

The development of learning objects was based on the methodology of User-Centered Design (UCD), as a method for facilitating the achievement of universal access to learning objects.
According to Preece et al (2005), the driving force behind the development of a product should be to support users and not limit their actions, in addition to getting the most of user feedback.

Preece et al (2005) point out that UCD is based on three principles:

a) early focus users and tasks: this involves understanding who the user is, which, in turn, requires "observing users doing their normal tasks, studying the nature of those tasks and then involving users in the design process" (pp. 305);

b) empirical measurement: early in the development, the reactions and performance of users are observed and measured. Users interact with simulations and prototypes, and "their performance and reactions are observed, recorded and analyzed" (pp. 305);

c) iterative design: the design process involves cycles of "designing, testing, assessing and redesigning", which are repeated several times, as needed.

Also according to Preece et al (2005), the usability goals ensure that products are easy to use and efficient. The usability goals are: effectiveness, efficiency, safety, utility, learnability and memorability.

Effectiveness defines how good the software is at doing what is expected of it. Efficiency aids users in performing their tasks; safety helps any user in any situation to avoid accidentally performing undesirable actions such as pressing the wrong keys by mistake, or undoing actions that had already been performed. The goal of utility refers to the extent to which the system provides the right kind of functionality. Learnability is the user's ability to learn how to use the system and memorability is the user's ability to remember how the system works after they have already learned how to do it.

From this perspective, the development process of learning objects involves the following steps:

a) Stage 1: consists of the direct observation of users. During this stage, the features required by the learning object, i.e., the requirements and restrictions are surveyed, as well as the expectations of users regarding the interface that will be developed;

b) Stage 2: this is the stage in which the learning objects are tested, i.e., it is in this stage that the child interacts with the interface and the compatibility between the user and the object of learning is assessed;

c) Stage 3: in this stage, the learning objects undergo adjustments, according to the possible shortcomings diagnosed during the testing phase. 
It should be noted that the learning objects are designed for use in mainstream schools, mostly in the public school system. Thus, it is understood that these interfaces should be developed using simple resources. This measure is a function of the need to ensure compatibility with the computer equipment used by schools, which is often outdated and lacking proper maintenance.

Therefore, the software used for the development of learning objects (LO) consisted of Microsoft Office PowerPoint and Microsoft Office Word, in addition to Corel Draw and Photoshop, which were used to developed some illustrations.

The LO developed are classified, according to the taxonomy of Wiley (2000), as combined-closed, i.e., a small number of digital resources combined in the design phase, which are not available individually.

The proposal and the development of interfaces and leaning objects took into account the stages of literacy process, which consist of learning and using writing language.

According to Teberosky (2003), the structure of written language is broken down into four distinct stages:

a) pre-syllabic writing: characterized by a lack of correspondence between letters and sounds;

b) syllabic writing: when the child discovers that the parts of the writing (letters) can be controlled through the syllables of the word;

c) syllabic-alphabetic writing: the combination of syllabic and alphabetic principles;

d) alphabetic writing: characterized by systematic and exhaustive correspondence between letters and phonemes, even if spelling is not conventional.

\section{Analysis and discussion of results}

In the development of LO for children with disabilities, it should be noted that the children have different experiences in relation to "ordinary" children, once they present with sensory-motor disorders that limit their experience of the world.

Thus, expectations may or may not be the same as for any child, although in many cases the symbolic appropriation can be different.

This study found that children and adolescents with cerebral palsy present with poorer performance when subjected to timed activities. This difficulty is, in most cases, related to the motor disorders that prevent/hinder the concrete performance of the task, even though the task has often already been completed mentally.
The application of usability goal of safety (measure that allows errors to be reversible) is essential for the construction of learning objects, especially for children and adolescents with cerebral palsy, considering that the possibility of error reversal minimizes frustration.

It is important to realize that the mobility or intellectual restrictions are accompanied by environmental restrictions. Most children with cerebral palsy, especially wheelchair users, have limitations in the way they experience environments and their knowledge is ultimately recognized and constructed limited to the home or therapeutic environments.

As an example, we noticed that when presented the image of a bee (in Portuguese, "abelha"), with the aim of symbolizing the letter A, children associated the image with a fly, an insect that is more commonly found at home. Therefore, it was necessary to test the recognition of other images, after which we came to the conclusion that, in this case, it would be more suitable to use the image of an airplane, an element that is commonly seen on television.

Once the child still does not associate the meaning to the written word, during pre-syllabic literacy illustrations and images can be read out loud. Thus, it is more difficult to explain the concepts of verbs than of nouns, which can be more easily represented in a concrete manner. "The pre-syllabics think that you can only write what you can draw" (HEIDRICH, 2004, pp. 86).

This confirmed the importance of constantly testing images in order to determine which are easily identified by children, in order for the association between images and text to be compatible.

The choice of location for the illustration proved to be essential to make the activity proposal consistent with the information in the literacy interface, since, depending on where the illustration is inserted, the child is induced to guess the meaning of words that are close together, because of the misuse of grouping and sorting criteria for the items presented.

According to Cybis et al (2000), there are two different possibilities for grouping and sorting. The first grouping and sorting possibility works by format, and, in this case, the similarities or differences are related through the shape of interface items or even through the use of visual sorting between areas of the screen. The second possibility works by location, which, in the case of the association of images and words, is related to the positioning of the image $i$ relation to the word. It should be clear to the user 
which items are being related, from the logical positioning between them.

To Filatro (2004), instructional design is related to the socio-constructivist thinking of Vygotsky, and she believes that surveying the students' learning profile and process is relevant to developing personalized tactics and custom.

Thus, it is understood that, when designing a learning object, one should prioritize the use of a language that is suitable for the child, so as to facilitate the understanding of the information that is being conveyed and to ensure that the information does not need to be recoded. The interface must be adapted to the social experiences of users, since this describes their stage of symbolic appropriation.

As stated by Nielsen (2000) and Preece et al (2005), the use of standards for performing tasks makes the activity more consistent, thus preventing users from having to decode different ways to accomplish the same task. Therefore, concise software minimizes the perceptual, cognitive and motor load associated with performing the tasks (CYBIS et al, 2000).

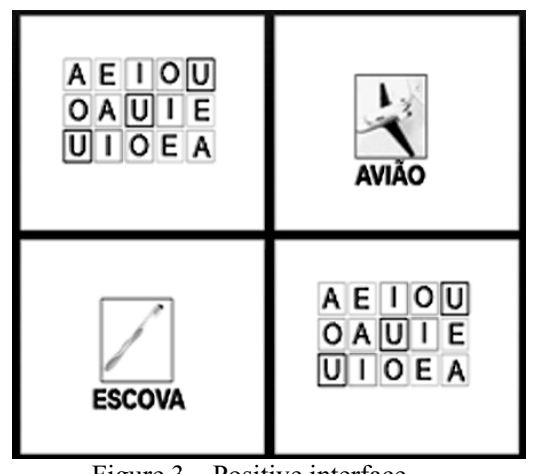

Figure 3 - Positive interface

Based on this information, interfaces were developed with characters from the show, combining educational purposes with an interesting topic. The topic is also suitable for the children in question, since many of them spend their days watching television, and leave the house only for therapeutic care, such as physiotherapy, speech therapy and others.

Filatro (2004) points out that the higher psychological functions are the product of cultural development rather than of biological development. Thus, for the author, learning is what sustains human development and not the opposite. These functions are defined by Fittipaldi (2006) as "voluntary functions," involving memory, attention, behaviors and imagination. They are developed from the interaction with the world and are mediated by instruments and signs, which interfere in the internal factors of human development.

Therefore, designing a learning object that is suitable for the user can facilitate the acquisition of new knowledge while also having an effect on the cognitive processes, so as to aid in the development of higher psychological functions. Another factor that should be considered when developing a learning object is readability, the relationship between the color of the peripheral (letters, images...) and the background color of the educational interface. Among the 20 participants of the research project, it was found that $20 \%$ of users prefer dark backgrounds (negative interface), while $80 \%$ prefer light backgrounds (positive interface).
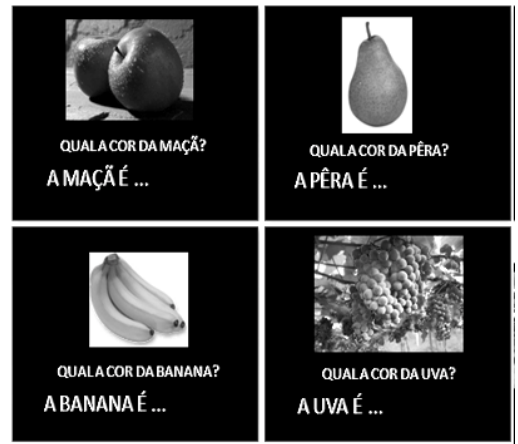

Figure 4 - Negative interface

\section{Conclusion}

This article presented the work of the Inclusive Design using information and communication technologies applied to education research project, in order to disseminate experiences and generate ideas for developing learning objects, specifically literacy interfaces for children and adolescents with cerebral palsy.

User-Centered Design proved to be an effective method to detect and provide solutions to the problems of incompatibility in the presentation and features of educational content.

The application of ergonomic safety criteria proved to be necessary in order for the task to be performed avoiding user frustration. Timed tasks are generally discouraging and misleading because they generate stress regarding the completion of the task.

Analyzing the profile of the educational interface user proved to be paramount to the construction of learning objects compatible with the user profile characteristics. The constant observation of this 
interaction allows for reassessment and different adjustments of the same learning object.

Finally, it is understood that ICT has helped both teachers and students in the process of inclusion in the regular school system, because they allow for individualized care, and are consistent with student characteristics, thus enabling the construction of knowledge and possibilities.

\section{References}

[1] Bartalotti, C. C. Inclusão social das pessoas com deficiência: utopia ou possibilidade? São Paulo: Paulus, 2006.

[2] Bobath, K. A Deficiência Motora em Pacientes com Paralisia Cerebral. São Paulo: Manole, 1976.

[3] Ciasca, S.M.; Moura-Ribeiro, V.L. e Tabaquim, M.L.M Aprendizagem e paralisia cerebral. In Rotta, N.T.; Ohlweiler, L. e Riesgo, R.S. Transtornos da aprendizagem - abordagem neurológica e multidisciplinar. Porto Alegre: Artmed, 2006.

[4] Cybis, W., Bertiol. A. H., Faust, R. Ergonomia e Usabilidade - Conhecimentos, Métodos e Aplicações. Florianópolis. Novatec, 2000.

[5] Cypel, S. O estudo das funções corticais na criança. In: Diament, A.; Cypel, S. Neurologia Infantil. São Paulo: Atheneu, 1996. pp. 10053-1056.

[6] Filatro, A. C. Design Instrucional Contextualizado. São Paulo: Senac, 2004.

[7] Fittipaldi, C. B. Conceitos centrais de Vygostky: implicações pedagógicas. Revista Educação, Vol. 1, Nº. 2. 2006 Available from:

$<$ http://revistas.ung.br/index.php/educacao/article/viewArticle/ 33>. Access in: 30 June, 2009.

[8] Fonseca, L.F. e Lelis, S.S.R. Abordagem neurológica da criança com paralisia cerebral: causas e exames complementares in Fonseca, L.F. e Lima, C.L.A. Paralisia Cerebral - neurologia, ortopedia e reabilitação. 2ed. Rio de Janeiro: MedBook, 2008.

[9] Heidrich, R. O. Análise de processo de inclusão escolar de alunos com paralisia cerebral utilizando as tecnologias de informação e comunicação. 2004. Porto Alegre: UFRGS. Doctoral Thesis.

[10] Heidrich, Regina de Oliveira; SILVA, Luciana Ferreira da; Martins, Maria Bernardete Rodrigues; Masotti, Miguel Severo. Apoio ergonômico de teclado - Ergonomic keyboard support. Estudos em Design, Rio de Janeiro, RJ, v. 14, n. 2 , Dec. 2006, pp. 9-25

[11] Heidrich, Regina de Oliveira; BASSANI, Patrícia Brandalise Scherer. Silveira, Clóvis da Avaliação das tecnologias de softwares existentes para a inclusão digital de deficientes visuais através da utilização de requisitos de qualidade. RENOTE - Revista Novas Tecnologias Na Educação, Porto Alegre, v. 5, n. 1 , 16 fl., Jul. 2007. 2006 Available from: $<$ http://ged.feevale.br/bibvirtual/Producao/2007/ClovisSilveira 191905.pdf>. Access in: 30 Oct. 2007

[12] Lamônica, D.A.C. Linguagem na paralisia cerebral. In Ferreira, L.P.; Befi-Lopes, D. e Limongi, S.C.O. Tratado de fonoaudiologia. São Paulo: Roca, 2004, pp. 1076.

[13] Lima, C.L.A. e Fonseca, L.F. Paralisia Cerebral. Rio de Janeiro: Guanabara Koogan e Medsi, 2004, pp. 492.

[14] Mallin, Sandra S. Vieira. Uma Metodologia de Design, aplicada ao desenvolvimento de tecnologia assistiva para portadores de paralisia cerebral. Curitiba: Editora da UFPR, 2004.

[15] Menezes, E. C. P. Informática e educação inclusiva discutindo limite e possibilidades. Santa Maria: UFSM, 2006.

[16] Miller, G.; Clark, G.D. Paralisias cerebrais: causas, conseqüências e conduta. São Paulo: Manole, 2002, pp. 409.

[17] Neri, M, C. Retratos da Deficiência no Brasil. Rio de Janeiro: FGV/IBRE, 2003

[18] Nielsen, J. Projetando Websites. Rio de Janeiro: New Riders, 2000 .

[19] Oliveira A. I. A.; Lourenço J. M. Q.; Lourenço M. G.F (Orgs). Perspectivas da Tecnologia Assistiva no Brasil: Pesquisa e Prática. UDUEPA. Belém PA. 2008.

[20] Optional Protocol to the Convention on the Rights of Persons with Disabilities. "Definition of Disability." Available from: $<$ http://www2.ohchr.org/english/law/disabilities-op.htm>. Access in: 14 June, 2009.

[21] Passerino, L. Pessoas com autismo em ambientes digitais de aprendizagem : estudo dos processos de interação social e mediação. Doctoral Thesis. Universidade Federal do Rio Grande do Sul. Programa de Pós-Graduação em Informática na Educação. 2005

[22] Preece, J., Rogers, Y., Sharp, H. Design de interação: além da interação homem-computador. Porto Alegre: Bookmam, 2005.

[23] Santarosa, L. Inclusão Digital: espaço possível para pessoas com necessidade educacionais especiais. In: Cadernos de Educação Especial, cidaden ${ }^{\circ} 20,2002$

[24] Satow, Suely Harumi. Paralisado cerebral: construção da identidade na exclusão. São Paulo:Cabral, 1996, pp 143.

[25] Teberosky, A., Colomer, T., Moll, J. Aprender a ler e escrever: uma proposta construtivista. Porto Alegre: Artmed, 2003.

[26] Tijiboy, Ana Vilma. Apropriação de Tecnologias de Informação e Comunicação no Desenvolvimento de Pessoas com Paralisia Cerebral. Doctoral Thesis: Universidade Federal do Rio Grande do Sul, UFRGS, Brazil. 2001. 